\title{
Passage of Radio-Iodinated Insulin through the Intestinal Wall of the Rat
}

\author{
A. D'Adpabbo, G. Fanfani and A. Muscogiurr
}

University Department of Medicine, (Director: Prof. V. ChIns), Bari, Italy

Received, August 31, 1966

Summary. ${ }^{131} \mathrm{I}$-insulin was given intravenously to normal rats, and the passage of radioactivity into the diodenal loop containing a proteasis inhibitor was studied by two techniques. In the first, the ${ }^{131} \mathrm{I}$-insulin was separated from the intestinal content by electrophoresis; whereas in the second, the radioactivity that remained on an ion-exchange resin, directly introduced into the small intestine, was measured. It was found that within 15 minutes from the injection a small amount of ${ }^{131} \mathrm{I}$ insulin passes into the gut lumen. - The absorption of ${ }^{131}$ I-insulin from small intestine into the blood was studied after introduction of ${ }^{131} \mathrm{I}$-insulin along with a proteasis inhibitor into the intestinal loop. The autoradiograph of the electrophoresis of serum showed plasma-protein-bound radioactivity but no radioactivity due to unbound (free) insulin- ${ }^{131}$ I. - These findings show that the passage of insulin through the intestinal wall of rats can be demonstrated by neutralizing the proteolytic activity in the intestinal tract. The possible role of this passage in protein-losing enteropathy is pointed out.

Passage d'insuline marquée à l'iode radioactif à travers la paroi intestinale du rat.

Résumé. Des rats normaux ont reçu de l'insuline-131I par voie intraveineuse et le passage de la radioactivité à l'intérieur du duodénum, contenant un inhibiteur de la protéolyse (Trasylol), a été déterminé par deux méthodes. Pour la première, l'insuline ${ }^{131}$ I a été séparée du contenu intestinal par électrophorèse, tandis que pour la deuxième, nous avons mesuré la radioactivité fixée sur résine échangeuse d'ions introduite directement dans l'intestin. Nous avons trouvé que 15 minutes après l'injection une petite quantité d'insuline passe dans la lumière intestinale. - L'absorption d'insuline-131I de l'intestin grêle vers le sang a été déterminée après introduction combinée d'insuline-131 I avec un inhibiteur de la protéolyse dans une anse intestinale. L' autoradiographie de l'électropho- rèse du sérum a montré une radioactivité liée aux protéines du plasma, mais pas d'insuline-131I non-liée (libre). - Ces recherches montrent que le passage d'insuline à travers la paroi intestinale du rat peut être démontré après neutralisation de l'activité protéolytique dans l'intestin. Un rôle possible de ce passage dans les entéropathies avec perte de protéines est suggéré.

Passage von radiojodmarkiertem Insulin durch die Darmwand der Ratte.

Zusammenfassung. Normale Ratten erhielten ${ }^{131} \mathrm{I}$-Insulin i.v., und der Ủbertritt der Radioaktivität in das Lumen des $Z$ wölffingerdarms, das einen Proteasen-Inhibitor (Trasylol) enthielt, wurde mittels zweier Verfahren untersucht. Bei dem ersten wurde das ${ }^{131}$ I-Insulin durch Elektrophorese vom Darminhalt getrennt, während beim zweiten ein Ionenaustauscher direkt in den Darm eingeführt und dann die daran haftende Radioaktivität gemessen wurde. Dabei fand sich, daß 15 Minuten nach der Injektion eine kleine Menge ${ }^{131}$ I-Insulin in das Darmlumen übertritt. - Die Absorption von ${ }^{131}$ I-Insulin aus dem Dünndarm in das Blut wurde nach Einbringen von ${ }^{131} \mathbf{I}$ Insulin zusammen mit einem Proteasen-Hemmer in die Darmschleife untersucht. Die Autoradiographie der Serumelektrophorese zelgte an Plasmaeiweiß gebundene Radioaktivität, jedoch kein nichtgebundenes (freies) ${ }^{131} \mathrm{I}-\mathrm{In}$ sulin. - Aus diesen Untersuchungen geht hervor, daß sich der Durchtritt von Insulin durch die Darmwand bei Ratten nach Neutralisierung der proteolytischen. Aktivität im Verdauungstrakt nachweisen läßt. Es wird auf die mögliche Bedeutung dieser Passage bei Enteropathien mit Eiweißverlust hingewiesen.

Key-words: ${ }^{131} \mathrm{I}$-labelled Insulin, Insulin leakage into intestine, Insulin absorption from intestine, Insulin catabolism, Iodide secretion and absorption, Gastrointestinal protein loss.
Previous investigations from a number of different laboratories $[24,10,6]$ have demonstrated that, even in normal subjects, several plasma proteins can be recognized in different segments of the gut lumen. In patients with protein-losing enteropathy the concentration of these proteins may be up to 50 times higher than the normal values, and it has been shown that the intestinal wall has no filtrating effect on the protein fractions $[23,18]$. The possibility therefore exists that in healty subjects even insulin, being a small molecule that has already been shown to pass into urine $[5,19,17,13]$, may pass through the wall of the gastrointestinal tract and that an increased leakage of this protein may occur in protein-losing enteropathy. The present study was designed to demonstrate this passage of ${ }^{131} \mathrm{I}$-insulin through the gut and intestinal mucosae.
Radio-iodinated insulin was administered to rats intravenously; qualitative determinations were then carried out by autoradiography of the electrophoretic strips of duodenal secretion.

${ }^{131}$ I-insulin was administered directly into the duodenal lumen of another group of rats and, in order to prevent its digestion in the intestine, it was associated with a kallikrein-inactivator (Trasylol ${ }^{\circledR} /$ Bayer, Leverkusen). Qualitative information was obtained from autoradiography of the electrophoretic strips of serum.

Furthermore, an approximate quantitation of the intravenously injected ${ }^{131} \mathrm{I}$-insulin passing into the intestine was obtained by measuring the radioactivity that had remained on an ion exchange resin (Amberlite IRA-400) directly introduced into the small intestine.

The excretion and absorption rates of insulin were compared with those of radioactive iodide. 


\section{Material and methods}

1. ${ }^{131}$ I-insulin. The labelling of crystalline beef insulin (Farbwerke Hoechst/Frankfurt) with iodide ${ }^{131}$ was performed according to the method of BANKs et al. [1]. The specific radioactivity at the time of use varied between 1.4 and 3.6 microcuries of ${ }^{131} \mathrm{I}$ per microgram insulin.

2. Paper electrophoresis. Paper electrophoresis with special paper strips (Bergmann/Berlin) was carried out in 0.05 barbital buffer $(\mathrm{pH} 8.6)$ at a constant voltage of 115 volts. Runs lasted for 10 hours.

3. Autoradiography. The time of exposure for the electrophoretic strips of radioactive insulin was 3 days, for the strips of sera it was 12 days and for the strips of duodenal secretion 18 days.

4. Counting techniques. Measurements of radioactivity were made in a well-type scintillation counter (Selo/ Milano), which has a sensitivity of $450000 \mathrm{cpm}$ per $\mu \mathrm{C}{ }^{131} \mathrm{I}$ in $3 \mathrm{ml}$, above a background of $200 \mathrm{cpm}$.

5. Experiments. Male Wistar rats between 250$300 \mathrm{~g}$ body weight were used. They were fasted for twelve hours prior to the experiments. To prevent uptake of ${ }^{131} \mathrm{I}$ by the thyroid, $0.1 \mathrm{~g}$ potassium iodide was administered twice on the day before the experiment. The operative procedures (laparotomy) were carried out under nembutal anaesthesia.

\section{the blood.}

Absorption of ${ }^{131} I$-insulin from small intestine into

a) $30 \mu \mathrm{C}$ of ${ }^{131}$ I-insulin in $3 \mathrm{ml}$ of kallikrein-inactivator (Trasylol, $15000 \mathrm{KIE}^{1}$ ) was introduced into the duodenal segment of 12 rats and blood samples were taken at 5-15 minutes intervals from the femoral veins. The radioactivity in $0.1 \mathrm{ml}$ of plasma was measured for about 110 minutes. The results were expressed as a percentage of the administered radioactivity.

b) In addition, the sera obtained from 2 rats 15 minutes after introduction into the duodenum of $500 \mu \mathrm{C}$ of ${ }^{131}$ I-insulin in $3 \mathrm{ml}$ of kallikrein-inactivator were used for electrophoresis and autoradiography.

c) Both procedures (a and b) were repeated by introducing ${ }^{131} \mathrm{INa}$ instead of ${ }^{131} \mathrm{I}$-insulin in order to distinguish the behaviour of iodinated insulin from the behaviour of iodide.

\section{Passage of ${ }^{131} I$-insulin into the intestinal lumen.}

d) $4 \mathrm{ml}$ volumes of wet amberlite IRA-400 $(0.5 \mathrm{~g}$ per $\mathrm{ml}$ of water) were introduced into the duodenum of 12 rats and the segment of the small intestine replete with amberlite was isolated between tape ligatures, one near the pylorus, and one about $20 \mathrm{~cm}$ distant from it. Afterwards the laparotomy wound was closed by continuous suture and $30 \mu \mathrm{C}$ of ${ }^{131} \mathrm{I}$-insulin was injected intravenously.

The animals were killed after 15 minutes by removing the greatest possible quantity of blood by

${ }^{1} \mathrm{KIE}$ is the quantity that inactivates, within $30 \mathrm{~min}$, at $37^{\circ} \mathrm{C}$ and $\mathrm{pH} 7.5,50 \%$ of 2 kallikrein units. cardiac puncture, care being taken to prevent the blood from entering the abdominal cavity and contamining the surface of the intestine. Then the isolated intestinal loop was removed and the duodenum was divided from the jejunum by ligature. The two loops were quickly slit open and the content of each of them determined individually. The resin-bound radioactivity was measured separately from the radioactivity of the intestinal wall. The values were expressed as a percentage of the administered radioactivity.
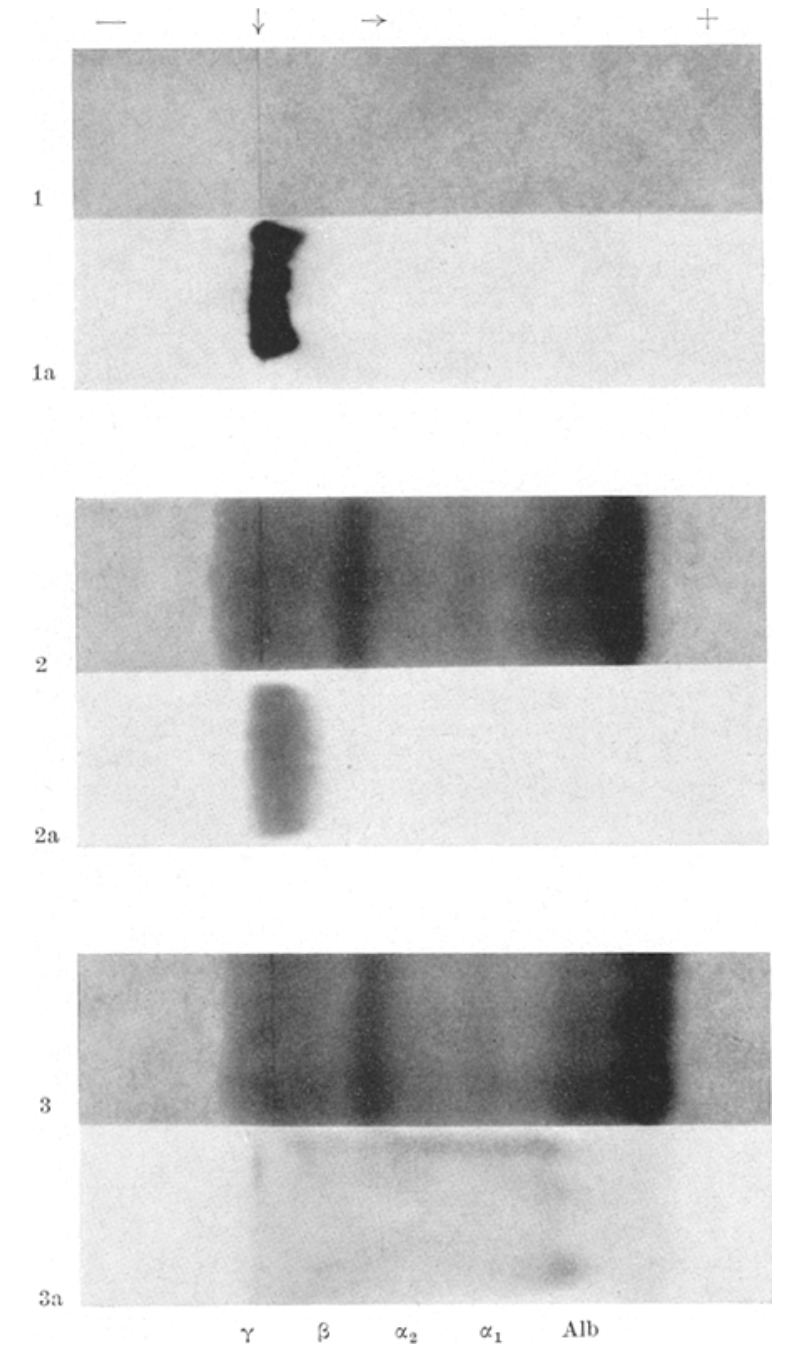

Fig. 1. Paper electrophoresis strips $(1,2,3)$ and autoradiographs $(1 a, 2 a, 3 a)$ of ${ }^{131}$ I-insulin

1. Paper electrophoresis pattern of $5.7 \mu \mathrm{g}{ }^{131} \mathrm{I}$-insulin

2. Paper electrophoresis pattern of $5.7 \mu \mathrm{g}{ }^{131} \mathrm{I}$-insulin $+0.008 \mathrm{ml}$ serum of rat 3. Paper electrophoresis pattern of $5.7 \mu \mathrm{g}^{1 \mathrm{si}} \mathrm{I}$-insulin $+0.008 \mathrm{ml}$ serum of rat $+0.01 \mathrm{ml}$ of commercial insulin (Hoechst) $=0.4 \mathrm{i}$. u. $=16 \mu \mathrm{g}$ insulin

e) In 2 rats the intestinal loop was filled with a $3 \mathrm{ml}$ volume of kallikrein-inactivator (Trasylol $15000 \mathrm{KIE}$ ) instead of amberlite, and $500 \mu \mathrm{C}$ of ${ }^{131} \mathrm{I}$ insulin was injected intravenously. 15 minutes later the contents of the loop were removed and used for electrophoresis and autoradiography after a 24 hours' dialysis. 
f) Both procedures (d and e) were repeated with ${ }^{131} \mathrm{INa}$ instead of ${ }^{131} I$-insulin.

Disappearance of ${ }^{131} I$-insulin from serum.

In 3 rats the disappearance rate of radioactivity from the blood stream was calculated after intravenous injection of $30 \mu \mathrm{C}$ of ${ }^{131} \mathrm{I}$-insulin. The same procedure was repeated with iodide.

\section{Results}

The insulin labelled with radioiodine was detected by exposing the electrophoretic strips against X-ray film for 3 days.

The findings agreed with those of previous investigations $[3,4]$ in that ${ }^{131}$ I-insulin in low concentrations, whether tested alone or mixed with serum, remained adsorbed to the paper at the starting point (Fig. 1, strip 1 and 2). According to KaLLeE [14, 15], migration of free ${ }^{131}$ I-insulin was obtained by adding a large excess of nonradioactive insulin as a specific carrier. The autoradiography of strip 3 showed that ${ }^{131}$ I-insulin then migrated with more or less the same mobility as albumin and alpha-globulins. However the inter-exchange between the labelled and non-labelled insulin and adsorption along the strip resulted in smearing and trailing of the labelled insulin.
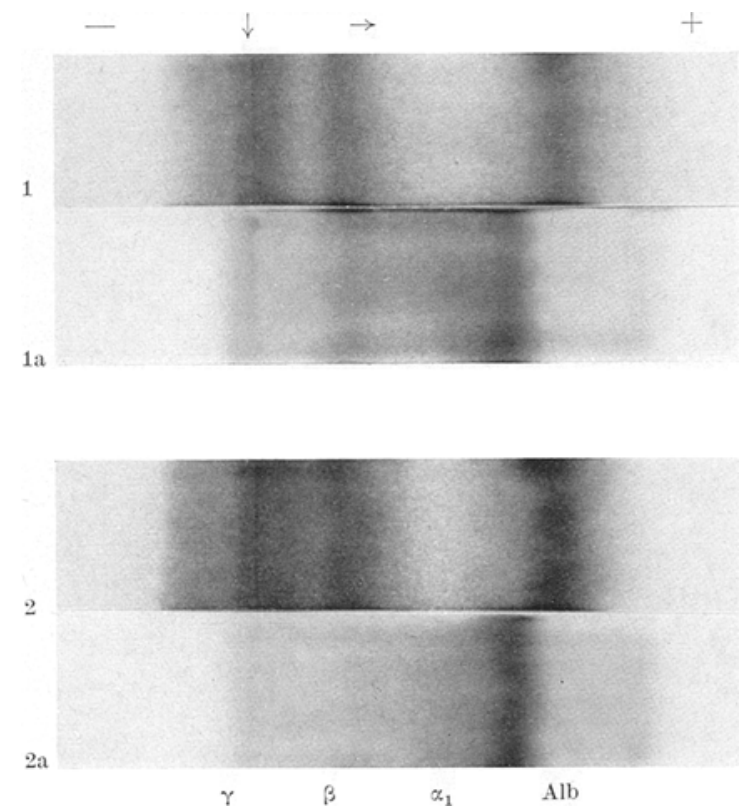

Fig. 2. Paper electrophoresis strips $(1,2)$ and autoradiographs $(1 \mathrm{a}, 2 \mathrm{a})$ of serum obtained 15 minutes after introduction of $500 \mu \mathrm{C}{ }^{131}$ I-insulin mixed with a kallikrein inactivator into the gut 1. Paper electrophoresis pattern of $0.008 \mathrm{ml}$ serum

2. Paper electrophoresis pattern of $0.008 \mathrm{ml}$ serum $+0.01 \mathrm{ml}$ commercial insulin (Hoechst) $=0.4 \mathrm{i} . \mathrm{u} .=16 \mathrm{~kg}$ insulin

Fig. 2 shows the autoradiographs of electrophoretic strips of serum obtained 15 minutes after introduction of $500 \mu \mathrm{C}{ }^{131} \mathrm{I}$-insulin mixed with $3 \mathrm{ml}$ of kallikreininactivator into the duodenum. The strips were exposed against $\mathrm{X}$-ray film for 12 days. The radioactiv- ity passing from intestine into blood was completely bound to plasma proteins, so that none remained at the starting point (strip 1). The main fraction of radioactivity was present in the alpha-globulin and beta-globulin bands, and a small amount in the prealbumin band. After addition of an excess of nonlabelled insulin, the radioactivity could be distinctly recognized only in the alpha-globulin and pre-albumin bands (strip 2).
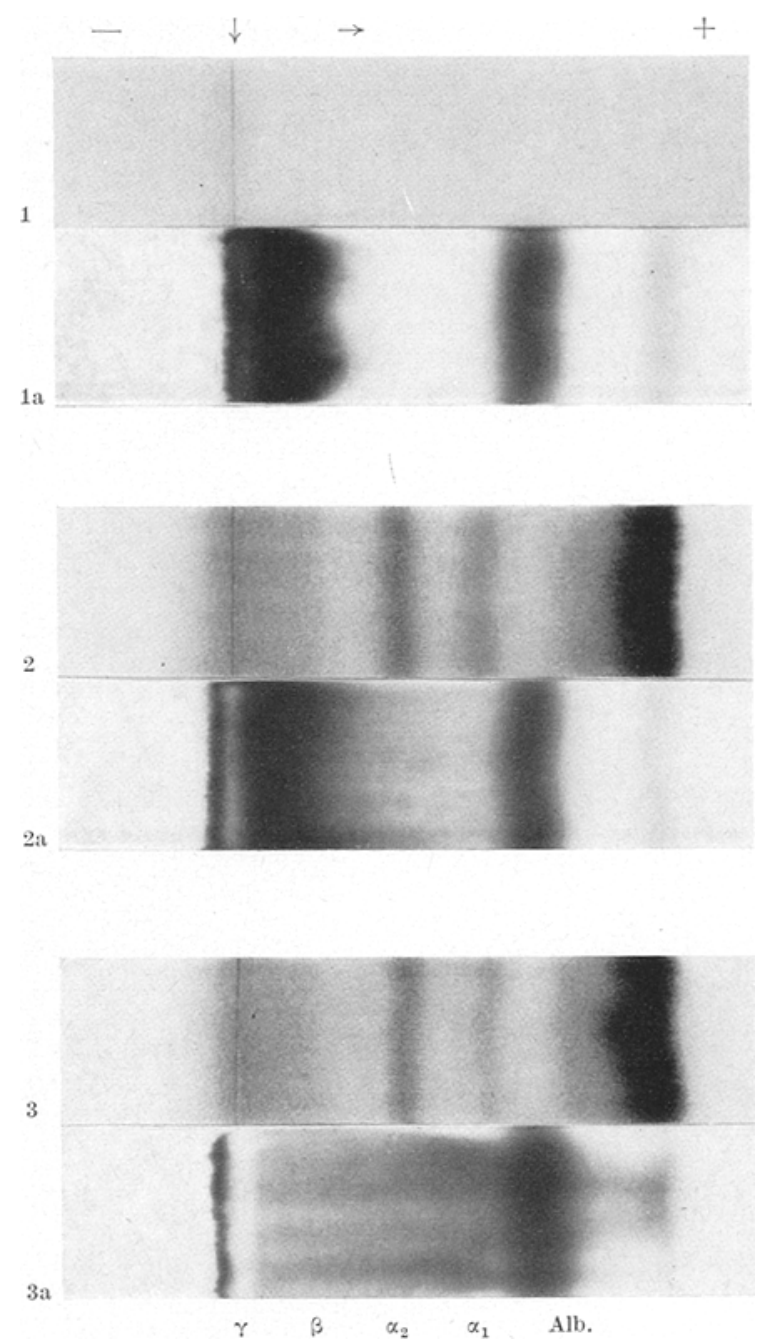

Fig. 3. Paper electrophoresis strips $(1,2,3)$ and autoradiographs (1a, 2a,3a) of the intestinal content after 15 minutes from intravenous injection of $500 \mu \mathrm{C}^{131} \mathrm{I}$-insulin

1. Paper electrophoresis pattern of $0.1 \mathrm{ml}$ of intestinal content

2. Paper electrophoresis pattern of $0.1 \mathrm{ml}$ of intestinal content $+0.008 \mathrm{ml}$ serum of non-treated rat

3. Paper electrophoresis pattern of $0.1 \mathrm{mI}$ of intestinal content $+0.008 \mathrm{mI}$ serum of non-treated rat $+0.01 \mathrm{ml}$ of commercial insulin (Hoechst) $=$ $0.4 \mathrm{i} . \mathrm{u} .=16 \mu \mathrm{g}$ insulin

Fig. 3 illustrates the electrophoretic strips and autoradiographs of the intestinal content 15 minutes after intravenous injection of $500 \mu \mathrm{C}{ }^{131} \mathrm{I}$-insulin. The strips were exposed against X-ray film for 18 days. The autoradiographs seem to indicate that ${ }^{131}$ I-insulin passes 
into the duodenum in two forms: one moving with the same mobility as albumin and inter-alpha-globulins, and one localized around the starting point (strip 1 and 2). By adding an excess of non-radioactive insulin to the duodenal secretion, the fraction previously adsorbed to paper around the starting point also moved. with a mobility equal to that of albumin and interalpha-globulins (strip 3).

Concerning the rats treated with ${ }^{131} \mathrm{INa}$, none of the autoradiographs, whether those of the electrophoretic strips of serum or those of the intestinal content, showed radioactivity when the electrophoretic run lasted for 10 hours.

Quantitative measurement. The serum radioactivity curve after introduction of ${ }^{131} \mathrm{I}$-insulin into the duodenum rises steeply during the first 8 minutes and then gently for the subsequent 99 minutes: the tracing shows a continuous rise, and when the sampling was stopped the radioactivity had not yet declined (Fig. 4).

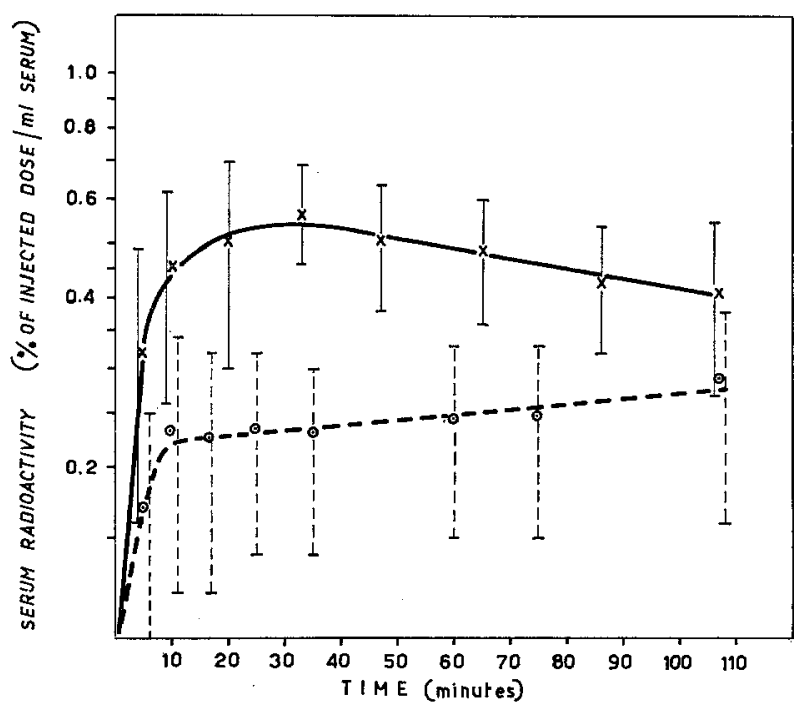

Fig. 4. Radioactivity values in serum of rats after administration into the duodenal lumen of ${ }^{101} \mathrm{I}$-insulin $(--\mathrm{O}--)$ and ${ }^{131} \mathrm{I} \mathrm{Na}(--\times--)$ mixed. with a kallikrein inactivator

Probably a much longer time is required for the plasma curve to reach its final slope. Whereas the curve of serum radioactivity after introduction of ${ }^{131} \mathrm{INa}$ rises rapidly for the first few minutes and reaches its maximum within 30 minutes (about 0.5 per cent of the administered dose $/ \mathrm{ml}$ serum). Then it declines at a rate similar to that of ${ }^{131}$ I disappearing from blood (Fig. 5). An explanation for this difference between the two curves may be given by the fact that the passage of ${ }^{131} \mathrm{I}$ insulin and its digested components from intestine into blood is delayed and of uneven velocity, whereas iodide passes more uniformly and more rapidly. The half-time of iodide (about 3 hours) was calculated from the descending part of the curve, and gave a result similar to the half-time of the disappearance rate of iodide from blood after intravenous injection.
Considerable difficulties beset any attempt to quantitate the passage of ${ }^{131} \mathrm{I}$-insulin into the intestinal loop because it is digested rapidly and the degradation products are reabsorbed. Only an approximate quantitation was possible using the ingenious resin technique [12]: the amberlite introduced into the loop prevented the reabsorption of the degradation products of the ${ }^{131}$ I-insulin which had passed into the intestinal lumen from blood. It should also be mentioned that any ${ }^{131}$ I

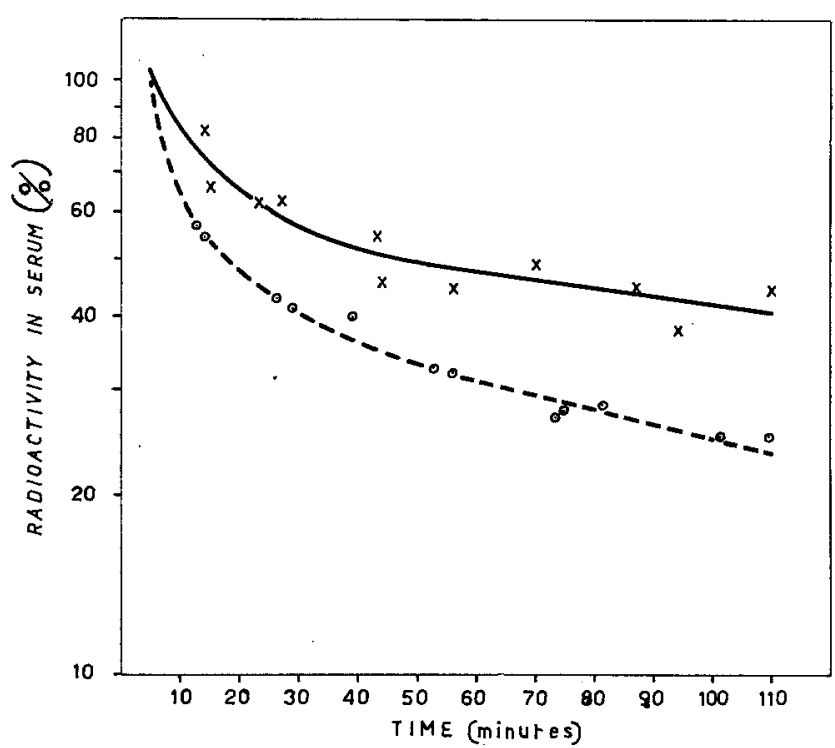

Fig. 5. Decrease of the radioactivity on serum related to the radioactivity 5 minutes after injection of ${ }^{181} \mathrm{I}$-insulin $(\ldots-\mathrm{O}--)$ and ${ }^{131} \mathrm{I} \mathrm{Na}(--\times--)$

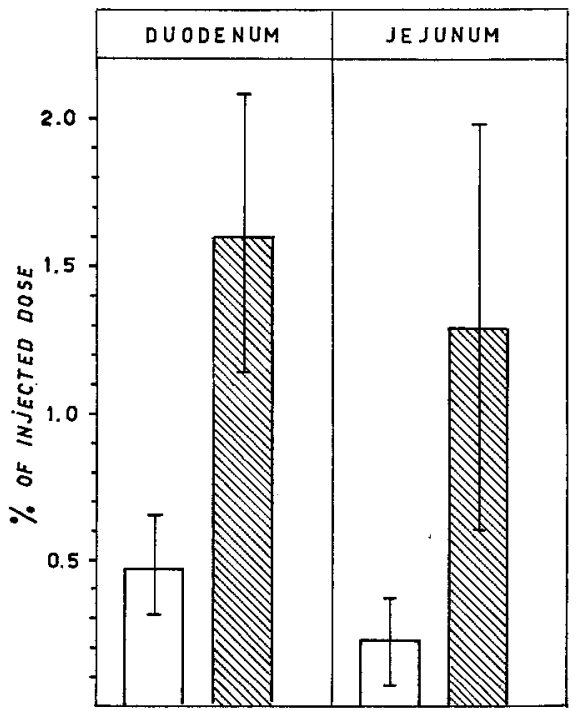

Fig. 6. Average values of radioactivity in amberlite 15 minutes after $i . v$ insulin ${ }^{131} \mathrm{I}(\square)$ and i. v. sodium iodide $-I^{181}(\boldsymbol{D})$

originating from the ${ }^{131} \mathrm{I}$-insulin catabolism in other sites of the body, principally in the liver or in the kidneys, could be secreted into the gut contents and be retained by the resin. 
In Table 1 the average values of radioactivity after 15 minutes from intravenous injection of ${ }^{131}$ I-insulin and ${ }^{131} \mathrm{INa}$ have been calculated per $\mathrm{ml}$ of amberlite as well as per em of intestine. The amount of amberlite in the duodenal segment was $0.11 \mathrm{ml} / \mathrm{cm}$ and in the jejunal segment $0.08 \mathrm{ml} / \mathrm{cm}$; the total amount in duodenum (average length $7 \mathrm{~cm}$ ) was $0.78 \mathrm{ml}$ and in jejunum (length $15 \mathrm{~cm}$ ) $1.21 \mathrm{ml}$.

The average values of radioactivity in the duodenum and jejunum after intravenous injection of ${ }^{131} \mathrm{I}$ insulin and ${ }^{131} \mathrm{INa}$ are presented in Fig. 6 . When related to the whole content of the isolated loops (about $20 \mathrm{~cm}$ of small intestine) the radioactivity represents $0.7 \%$ of the injected dose of ${ }^{131} \mathrm{I}$-insulin and about $3 \%$ of the injected dose of ${ }^{131} \mathrm{INa}$.

Since it is almost impossible to fill the whole of the gut uniformly with amberlite, it is difficult to estimate, from data obtained in a small segment, the extent of leakage of ${ }^{131}$ I-insulin in the whole intestinal tract.
Any attempts at quantitation of ${ }^{131} \mathrm{I}$-insulin in the intestine are bound to be difficult and a wide latitude in calculation must be accepted on common-sense grounds at the present time. The radioactivity that remained on the amberlite represents that of intact insulin [21], as well as that of its intestinal breakdown products. This may be deduced from the above-described electrophoretic and autoradiographic demonstration of the radioactivity components in the intestinal content (Fig. 3).

Owing to the limitation of the resin technique [21, $9,7]$, however, we cannot at the present time assess how much the iodide liberated by the ${ }^{131} \mathrm{I}$-insulin catabolism anywhere in the body contributed to the resinbound radioactivity. In any case, on the grounds of the data obtained, we can affirm that in normal rats ${ }^{131}$ I-insulin passes through the intestinal wall in small amounts.

The other aspect of the present experiments con-

Table 1. Concentration of radioactivity in intestine of rats 15 min. after $i . v$. insulin- ${ }^{191} I$

\begin{tabular}{lllll}
\hline $\begin{array}{l}\text { Intestinal loop } \\
\text { (length) }\end{array}$ & $\begin{array}{l}\text { No. of } \\
\text { rats }\end{array}$ & $\begin{array}{l}\text { \% of dose per ml } \\
\text { amberlite. }\end{array}$ & $\begin{array}{l}\text { \% of dose per amberlite } \\
\text { contained in 1 cm of } \\
\text { intestine }\end{array}$ & $\begin{array}{l}\% \text { of dose per cm } \\
\text { intestinal tissue }\end{array}$ \\
\hline $\begin{array}{l}\text { Duodenum } \\
(7 \mathrm{~cm})\end{array}$ & 12 & $0.225 \pm 0.150$ & $0.025 \pm 0.017$ & $0.054 \pm 0.016$ \\
$\begin{array}{l}\text { Jejunum } \\
(15 \mathrm{~cm})\end{array}$ & 12 & $0.476 \pm 0.170$ & $0.040 \pm 0.014$ & $0.032 \pm 0.014$ \\
\hline
\end{tabular}

Concentration of radioactivity in intestine of rats 15 min. after $i . v .{ }^{131} I N a$

\begin{tabular}{|c|c|c|c|c|}
\hline $\begin{array}{l}\text { Intestinal loop } \\
\text { (length) }\end{array}$ & $\begin{array}{l}\text { No. of } \\
\text { rats }\end{array}$ & $\begin{array}{l}\% \text { of dose per } \mathrm{ml} \\
\text { amberlite }\end{array}$ & $\begin{array}{l}\% \text { of dose per amberlite } \\
\text { contained in } 1 \mathrm{~cm} \text { of } \\
\text { intestine }\end{array}$ & $\begin{array}{l}\% \text { of dose per cm } \\
\text { intestinal tissue }\end{array}$ \\
\hline $\begin{array}{l}\text { Duodenum } \\
(7 \mathrm{~cm})\end{array}$ & 12 & $1.286 \pm 0.691$ & $0.144 \pm 0.072$ & $0.070 \pm 0.024$ \\
\hline $\begin{array}{l}\text { Jejunum } \\
(15 \mathrm{~cm})\end{array}$ & 12 & $1.613 \pm 0.472$ & $0.137 \pm 0.040$ & $0.044 \pm 0.021$ \\
\hline
\end{tabular}

\section{Discussion}

The present work has given evidence that ${ }^{131} \mathrm{I}$ insulin passes through the intestinal wall of the rat. 15 minutes after intravenous injection, ${ }^{131} \mathrm{I}$-insulin can be demonstrated electrophoretically in the duodenal content: the main fraction of radioactitivy was localized around the starting point and a small fraction had migrated more or less nonspecifically with plasma proteins. Since it has long been recognized that intact ${ }^{131}$ I-insulin remains adsorbed to the paper at the starting point while ${ }^{131}$ I migrating with the plasma proteins is bound to the damaged components of the labelled insulin [2], it can be deduced that the duodenal secretion also contains a portion of altered ${ }^{131} \mathrm{I}$-insulin. This is not surprising since insulin, being a relatively small protein molecule, readily passes across the capillary wall and can be degradated both in the extravascular spaces of the intestinal tissue and in the intestinal lumen. Presumably the proteasis inhibitor introduced into the duodenum had only partially protected the 131I-insulin from digestion. cerns the absorption of ${ }^{131} \mathrm{I}$-insulin from intestine. According to LASKOWskI et al. [16], absorption of insulin in a physiologically active form occurs from an intestinal loop in rats when insulin digestion has been prevented by the administration of a trypsin-inhibitor. INOUYE and VARS [11] demonstrated insulin absorption from small and large intestines of dogs after simultaneous administration of a kallikrein inactivator. HABERLAND et al. [8] showed that the amount of absorption in rats depends on the dose of both insulin and kallikrein inactivator injected into the gut lumen. The passage of insulin through the wall of the gastrointestinal tract has also been demonstrated by MoSINGER et al. [22] in new-born rats without tryptic activity of the intestine and pancreas.

In our experiments the autoradiography of the electrophoretic strip of serum, taken 15 minutes after introduction of ${ }^{131} \mathrm{I}$-insulin and kallikrein-inactivator into the duodenum, shows plasma-protein-bound radioactivity but no radioactivity due to unbound (free) insulin-131I. There are three possible explanations for these results: 1 . the absorption of ${ }^{131}$ I-insulin from the 
small intestine requires a much longer time, so that at about 15 minutes only its hydrolysed components are circulating in the blood stream; 2. ${ }^{131}$ I-insulin has been completely digested because of an insufficient dose of proteasis inhibitor; 3. labelled insulin was destroyed in the liver by the enzymatic "insulinase" system [20]. The observations of HaBERLaND et al. support the first thesis: they showed that the hypoglycaemic effect of insulin absorbed from intestine occurs in healthy rats $1 \frac{1}{2}$ to 3 hours after introduction of insulin into the intestine. The absorption curve of ${ }^{131}$ I-insulin resulting from our investigations also gives support to the view that insulin requires some time to become absorbed from the enterohepatic circulation. Indeed, the concentration of radioactivity in the blood stream of the ${ }^{131} \mathrm{I}$-insulin-treated rats was lower than that of the ${ }^{131} \mathrm{INa}$-treated animals, and the absorption process turned out to be slower.

On the basis of these data it can be concluded that a two way movement of insulin across the intestinal wall is possible. Studies are in progress on the role of this passage in protein-losing enteropathy.

\section{References}

[1] Banks, H.H., A.M. Seligman and J. Fine: The effect of hyaluronidase on the absorption of parenterally administered radioactive plasma proteins in the dog. J. clin. Invest. 28, 548-552 (1949).

[2] Berson, S.A., and R.S. YaLow : Radiochemical and Radiobiological Alterations of $I^{131}$-labelled Proteins in solution. Ann. N.Y. Acad. Sci. 70, 56-68 (1957).

[3] - - A. Bauman, M.A. Rothschild and K. NEWERLY: Insulin- $\mathrm{I}^{131}$ metabolism in human subjects: Demonstration of insulin binding globulin in the circulation of insulin-treated subjects. J. clin. Invest. 35, $170-190(1956)$.

[4] Burrows, B.A., T. Peters and F.C. Lowelu: Physical binding of insulin by gamma globulins of insulinresistant subjects. J. clin. Invest. 36, 393-397 (1957).

[5] D'Adpabbo, A., G. Seybold und E. Kallee: Der Einfluß von Hydrochlorothiazid auf die Insulinwirkung und den Abbau von ${ }^{131} \mathrm{I}$-Insulin beim Kaninchen. Z. ges. exp. Med. 138, 105-115 (1964).

[6] Frenman, T.: The gastrointestinal tract as a site for catabolism of plasma proteins. In "The role of the gastrointestinal tract in protein metabolism", p. 125. Edited by H.N. Munro, Oxford: Blackwell, 1964.

[7] - , and H. GoRDON: The measurement of albumin leak into the gastrointestinal tract using ${ }^{131} \mathrm{I}$-albumin and ion exchange resin by mouth. Gut 5, 155-157 (1964).

[8] Haberland, G.L., J. Pütter und W. Puls: Die enterale Resorption von Insulin mit Hilfe von Trasylol. Med. Pharmacol. Exp. 14, 297 -304 (1966).
[9] Høent-Rassmussen, K., and E. Kemp: The measurement of gastrointestinal protein loss by ${ }^{131} I$-labelled protein and resin. Gut 5, 158-159 (1964).

[10] Holman, H., W.F. Nickel and M.H. Sletsenger: Proteinaemia antedating intestinal lesions, and possibly due to excessive serum protein loss into the intestine. Amer. J. Med. 27, 963-975 (1959).

[11] InOUYE, W.Y., and H.M. VARs : Cited in reference 8.

[12] JeE.JEEBHoy, K.N., and N.F. Coghilt: The measurement of gastrointestinal protein loss by a new method. Gut 2, 123-130 (1961).

[13] JøRgENSEN, K.R.: Immunoassay of insulin in human urine. Acta endocr. 51, 400-410 (1966).

[14] Kaldies, E.: Über ${ }^{131}$ I-signiertes Insulin. I. Mitteilung (Nachweis). Z. f. Naturforsch. 76, 661-663 (1952).

[15] - Über ${ }^{131}$ I-signiertes Insulin. II. Anwendungsbereich und Grenzen der Nachweismethode. Klin. Wschr. 32, 508-509 (1954).

[16] Laskowski, M. Jr., H.A. Haessler, R.P. Мuech, R.J. PEANASKY and M. LAskowski : Effect of trypsin inhibitor on passage of insulin across the intestinal barrier. Science 127, 1115-1116 (1958).

[17] LrBERManN, L. L.: Evidence of the presence of insulin in the urine. Bull. exp. Biol. Med. (N.Y.) 55, 639 (1964).

[18] Märki, H.H., und F. Wuhrmann: Proteinverlustsyndrome. Zur Pathogenese der Hypoproteinaemie beim nephrotischen Syndrom und beim enteralen Proteinverlust. Schweiz. med. Wschr. 91, 1521-1529 (1961).

[19] McArThuR, R.G., and L. STIMMLER: Urinary insulin excretion in healthy children and in siblings of childhood -onset diabetics. Lancet 1966 II, 1236-1237.

[20] Mirsky, I.A., G. Perisutit and F.J. Dixon: The destruction of ${ }^{131} \mathrm{I}$-labelled insulin by rat liver extracts. J. biol. Chem. 214, $397-408$ (1955).

[21] Mrtchele, M.L., W.O. Whitehead and M.E. O'RouRke: Differential resin binding of insulin in serum. Endocrinology 65, 322-336 (1959).

[22] Mosinger, B., Z. Puader and O. Koldovsky: Passage of insulin through the wall of the gastrointestinal tract of the infant rat. Nature 184, 1245$1246(1959)$.

[23] Nusslé, D., S. Barandun, H.P. Witschx, H. Käser, M. BetTex and P. Girardet: Déperdition intestinale de protéines plasmatiques chez l'enfant. Aspects étiologiques et pathogéniques. Helv. paediat. Acta 16, Suppl. X (1961).

[24] Riva, G., S. Barandun, T. Koblet, D. Nusslé and H.P. WrTschI: Proteinverlierende Gastroenteropathien: Klinik und Pathophysiologie. In "Protides of the Biological Fluids", Proceedings of the 11th Colloquium, Bruges, p. 168; Amsterdam-London-New York: Elsevier 1963.
A. D'AdDabBo
Laboratorio Radioisotopi
Istituto di Clinica Medica
dell'Università
Bari, Italia 